Unbecoming Americans 



\section{UnbeCOMING AmericAns}

Writing Race and Nation from the Shadows of Citizenship, 1945-1960

JOSEPH KEITH

Rutgers University Press

NEW BRUNSWICK, NEW JERSEY, AND LONDON 
Keith, Joseph.

Unbecoming Americans : writing race and nation from the shadows of citizenship, 1945-1960 / Joseph Keith.

p. $\mathrm{cm}$.

Includes bibliographical references and index.

ISBN 978-0-8135-5967-4 (hardcover : alk. paper)

ISBN 978-0-8135-5966-7 (pbk. : alk. paper)

ISBN 978-0-8135-5968-1 (e-book)

1. American literature-Minority authors-History and criticism. 2. Immigrants' writings, American-History and criticism. 3. Citizenship in literature. 4. Race in literature. 5. American literature-2oth century-History and criticism. I. Title. PS153.M56K44 2013 $810.9 ' 920693-\mathrm{dc} 23$

A British Cataloging-in-Publication record for this book is available from the British Library.

Copyright (๑) 2013 by Joseph Keith

All rights reserved

No part of this book may be reproduced or utilized in any form or by any means, electronic or mechanical, or by any information storage and retrieval system, without written permission from the publisher. Please contact Rutgers University Press, 106 Somerset Street, New Brunswick, NJ 08901. The only exception to this prohibition is "fair use" as defined by U.S. copyright law.

Visit our website: http://rutgerspress.rutgers.edu

Manufactured in the United States of America

THE

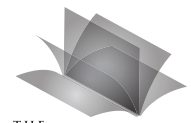

A M E R I C A N

LITERATURES

I N I T I A T I V E
A book in the American Literatures Initiative (ALI), a collaborative publishing project of NYU Press, Fordham University Press, Rutgers University Press, Temple University Press, and the University of Virginia Press. The Initiative is supported by The Andrew W. Mellon Foundation. For more information, please visit www.americanliteratures.org. 
For my parents, Christopher and Margaret Keith 
